\title{
The effect of epiphytic macroinvertebrates on microbial communities in different types of macrophyte-dominated shallow lakes
}

\author{
Tomasz Mieczan ${ }^{1, *}$, Monika Tarkowska-Kukuryk ${ }^{1}$, Diana Ârva ${ }^{2}$, Làszló Berzni-Nagy ${ }^{2}$, Zoltan Novak $^{2}$ \\ and Csilla Vajda ${ }^{2}$ \\ ${ }^{1}$ Department of Hydrobiology and Protection of Ecosystems, University of Life Sciences, Dobrzańskiego 37, 20-262 Lublin, Poland \\ ${ }^{2}$ Department of Hydrobiology, University of Debrecen, Egyetem tér 1, 4032 Debrecen, Hungary
}

\begin{abstract}
Complex interactions between epiphytic fauna and microbial food webs in periphyton are vital to the ecosystem ecology of shallow lakes. However, little is known about how different types of macrophyte dominated lakes may influence microbial and metazoan communities. The goal of the present study was to examine the impact of metazoan on microbial food web in three different types of lakes (Stratiotes-dominated, Ceratophyllum-dominated and Potamogeton-dominated). The results of this study suggest a strong correlations between chironomid larvae, small Metazoa and microbial communities in the periphyton of macrophyte-dominated lakes. Weak relations between food web components were found in the Potamogeton-dominated and Ceratophyllum-dominated lakes, where environmental variables explained the bulk of the total variance in periphyton abundance, whereas strong predator-prey relations were noted in the Stratiotes-dominated lake, where environmental variables had a minor role in the total variance in periphyton abundance. Our study contributes to knowledge of the functioning of eutrophic lakes in the current era of increasing eutrophication caused by climate change and human activity.
\end{abstract}

Keywords: Periphyton / food web / eutrophication / macrophyte / microbial communities

Résumé - L'effet des macroinvertébrés épiphytiques sur les communautés microbiennes dans différents types de lacs peu profonds dominés par les macrophytes. Les interactions complexes entre la faune épiphytique et les réseaux trophiques microbiens dans le périphyton sont essentielles à l'écologie des écosystèmes des lacs peu profonds. Cependant, on sait peu de choses sur la façon dont différents types de lacs dominés par les macrophytes peuvent influencer les communautés microbiennes et métazoaires. L'objectif de la présente étude était d'examiner l'impact des métazoaires sur la chaîne alimentaire microbienne dans trois différents types de lacs (dominés par Stratiotes, dominés par Ceratophyllum et par Potamogeton). Des relations faibles entre les composantes du réseau trophique ont été observées dans les lacs dominés par Potamogeton et Ceratophyllum, où les variables environnementales expliquaient la plus grande partie de la variance totale de l'abondance du périphyton, alors que les relations prédateurs-proies étaient fortes dans le lac à Stratiotes. Les variables environnementales ont joué un rôle mineur dans la variance totale de l'abondance du périphyton. Notre étude contribue à la connaissance du fonctionnement des lacs eutrophes dans la période actuelle d'eutrophisation croissante causée par le changement climatique et l'activité humaine.

Mots-clés : Périphyton / chaine alimentaire / eutrophisation / macrophyte / communautés microbiennes

\section{Introduction}

Submerged macrophytes constitute a key element in the functioning of food webs of shallow lakes and promote clear

*Corresponding author: tomasz.mieczan@up.lublin.pl water conditions (Jeppesen et al., 1998, 2000, 2007; Schindler and Scheuerell, 2002). Shallow lakes, especially small ones with extensive littoral areas, have a high potential for periphyton growth (Wetzel, 1990; Vermaat, 2005; Grutters et al., 2017; Zeng et al., 2017). The periphyton assemblage associated with macrophytes is a complex structure composed of algae, bacteria, fungi, protozoa, small metazoans, and macroinvertebrates. In general, both the structure and abundance of periphyton 


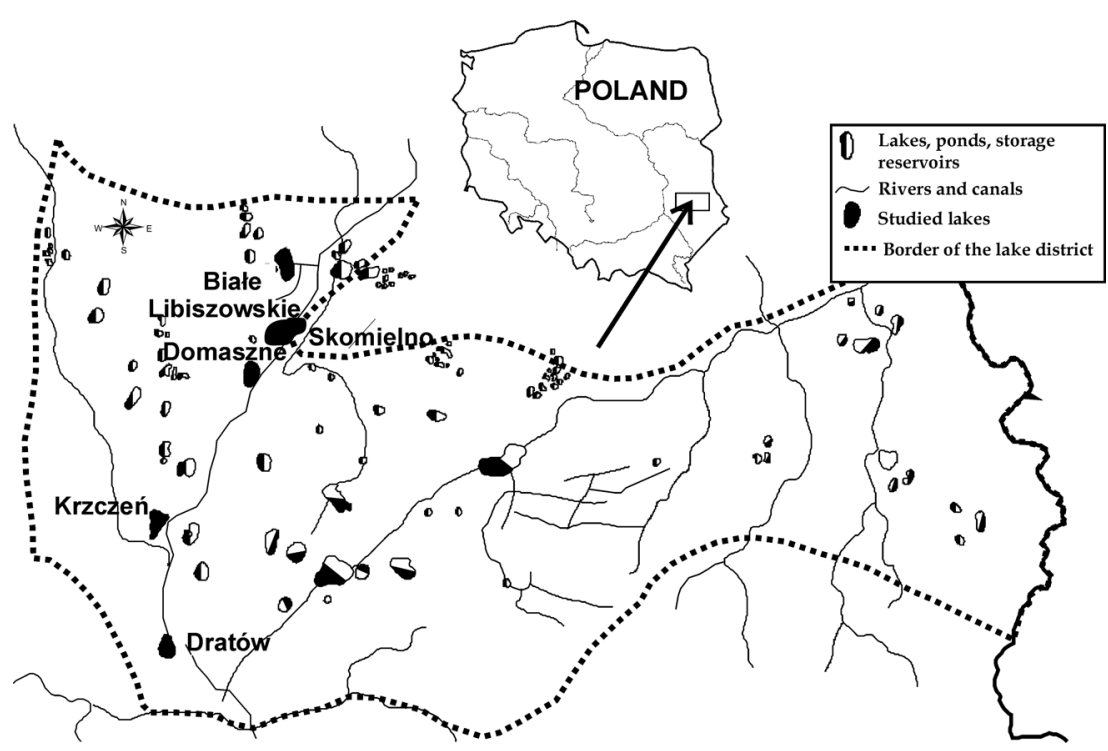

Fig. 1. Study area.

communities are affected by available resources (nutrients and light) and by predation by higher trophic levels (grazing) (Kairesalo et al., 2000; Zhang et al., 2013; Hao et al., 2017). However, little is known about the periphytic microbial communities inhabiting lakes dominated by different types of macrophytes. Understanding the flow of matter and energy through an ecosystem, as described in food web theory, is of paramount importance (Pomeroy, 1974; Segovia et al., 2015). Microbial communities are regulated both by top-predator grazing (top-down control) and nutrient resources (bottom-up control), and the strength of this control is dependent on trophic position and food web length (Pierce and Turner, 1992; Biyu, 2000; Xu et al., 2005). Metazoan grazing is an important process for the recycling of nutrients and the production of dissolved organic substrates for bacteria, it is also a controlling factor for heterotrophic protist community structure (Fermani et al., 2013; Mieczan and Tarkowska-Kukuryk, 2013). However, there have been very few studies on the influence of epiphytic fauna on microbial food webs in periphyton on different macrophyte species of shallow lakes. Macrophyte tissues release biologically active chemicals which may influence algal growth (Jones et al., 2000); the taxonomic composition and biomass of periphytic algae associated with natural and artificial substrata are structured by the grazing pressure of higher trophic levels. Invertebrate grazers may show preferential feeding, grazing mostly on highly edible and nutritious algae and keeping periphyton biomass low (Jones and Sayer, 2003); the taxonomic composition and abundance of invertebrate grazers are influenced by substrate type and food (algae biomass and availability). Dipterans are more distributed in shallow lakes (Jones and Sayer, 2003; Obolewski and Bąkowska, 2017). Due to their high densities, rapid growth and high grazing rates, chironomid larvae have great potential to regulate the abundance of lower trophic levels. The most commonly reported ingested food in freshwater ecosystems is detritus with associated protozoans and algae (Lawrence and Gresens, 2004; Enterkin et al., 2007). However, the impacts of chironomid larvae on periphyton communities need to be explicitly examined because chironomids exert bottom-up controls as well as top-down controls through excretion and regeneration of nutrients (Wickham et al., 2004). Thus the study aims to analyse the diet composition of chironomid larvae and evaluate the role of protozoans, algae, rotifers and copepods as food items. The specific goals of the study were: (i) to analyse the taxonomic composition and abundance of periphytic algae, ciliates, Metazoa and chironomids on different species of macrophytes; (ii) to describe environmental variables responsible for the distribution of microand macro-organisms on different macrophytes and interactions between components of the periphytic food web.

\section{Material and methods}

\subsection{Study site}

The study area comprised five shallow (depth 1.5-2.2 m), eutrophic and polymictic lakes (Skomielno, Dratów, Krzczeń, Domaszne and Białe Libiszowskie) in the Polesie Lubelskie region of eastern Poland $\left(51^{\circ} \mathrm{N}, 23^{\circ} \mathrm{E}\right)$ (Fig. 1). The lakes represent three types of macrophyte community (Dawidek et al., 2004; Tarkowska-Kukuryk and Mieczan, 2017). Lake Skomielno is classified as Stratiotes-dominated, Lakes Białe Libiszowskie and Dratów are classified as Potamogetondominated, with total coverage of the bottom ranging from $7 \%$ to $11 \%$; Potamogeton crispus L. dominated in the species structure with five accompanying macrophyte species: Ceratophyllum demersum L., Potamogeton lucens L., Myriophyllum spicatum L. and Stratiotes aloides L. The other two lakes, Krzczeń and Domaszne, represent the Ceratophyllumdominated type. The total area overgrown by submerged vegetation varied between $28 \%$ and $39 \%$; $C$. demersum dominated in the species structure, with the accompanying species M. spicatum, P. crispus and Potamogeton pectinatus L.

\subsection{Sampling and identification}

Samples of periphytic microbial communities (bacteria, algae, heterotrophic flagellates (HF) and ciliates), rotifers, cladocerans, copepods and macro-invertebrates were taken in 
April, July and October 2012-2013. In each of the study seasons three samples were collected from the littoral habitat, so that 90 samples (45 each in 2012 and 2013) were collected in spring, summer and autumn in these lakes. The periphyton communities were sampled from natural substrata, i.e. S. aloides L., P. crispus L. and C. demersum L., at a depth of $0.5-$ $1 \mathrm{~m}$ in the littoral zone. Samples of periphytic algae, microbial communities and small metazoan were taken by cutting off a plant in a water column and placing it in a plastic bag. The contents of each bag were transferred to a plastic bottle filled with $300 \mathrm{~mL}$ of lake water filtered through $0.2 \mu \mathrm{m}$ pore-size filters. Epiphytic algae were separated from the plant by shaking vigorously for two minutes. The suspension was filtered through $300 \mu \mathrm{m}$ mesh to avoid contamination with small plant fragments or occasional invertebrates. From this sample, a $100 \mathrm{~mL}$ algal sample was fixed with Lugol's solution and then with a formalin-glycerine solution. A $2 \mathrm{~mL}$ aliquot was taken from the subsample and placed in a $10 \mathrm{~mL}$ Utermöhl counting chamber and then filled with filtered water $(\mathrm{GF} / \mathrm{C}$ filter). After settling, at least 200 algal cells were counted along one or more grid lines. All cells of colonial algae were counted; each filament with a length of $100 \mu \mathrm{m}$ was counted as one cell. Counting and identification were performed at $400 \times$ magnification under an inverted microscope equipped with a calibration micrometer. Taxonomic identification was based on keys by van den Hoek et al. (1995). The biomass of the periphytic algae was calculated using the lengths and widths of algal cells and common geometric equations (Rott, 1981), and expressed in micrograms per $100 \mathrm{~g}$ of dry weight (DW) of plant. The plant fragments collected for the analysis were dried at $105^{\circ} \mathrm{C}$ for $24 \mathrm{~h}$ and then weighed to obtain the DW. The relative abundance of algal taxonomic groups was estimated in the total biomass of algae, based on the biomass of counted cells and filaments. To extract the different groups of microand macro-organisms from the macrophytes, each sample was first shaken for $1 \mathrm{~min}$ with a vortex and then filtered through a $250 \mu \mathrm{m}$ mesh filter. The volume of water extracted from the Plexiglas corer ranged from 400 to $500 \mathrm{ml}$. During each sampling occasion (season) three replicate samples were collected from lakes. Abundances of bacteria were determined using DAPI (46-diamino-2-phenylindole) (Porter and Fleig, 1980). Water samples of $10 \mathrm{~mL}$ were preserved in formaldehyde to a final concentration of $2 \%$ and kept in darkness at $4{ }^{\circ} \mathrm{C}$. Preparations were made within $24 \mathrm{~h}$ after sampling. Four slides were made from each sample, with $2 \mathrm{~mL}$ subsamples filtered on $0.2 \mu \mathrm{m}$-pore-size polycarbonate filters stained with irgalan black. Epifluorescence microscopy (Nikon, Eclipse) was used to determine total bacterial cell numbers $(1.250 \times$ magnification, an HB2-RFL epifluorescence illuminator, a HB0-100W mercury lamp, and a 100/1.25 neofluor objective lens). Bacteria were chosen from 5 to 10 randomly selected fields of each microscope slide and 250-300 cells per slide were counted.

Abundances of HF were determined with primuline solution (Caron, 1983). Water samples of $10 \mathrm{~mL}$ were collected into dark sterilized bottles. The samples were preserved in formalin to a final concentration of $2 \%$ and kept in darkness at $4{ }^{\circ} \mathrm{C}$. Four preparations were made from each sample. Sub-samples were condensed on $0.8 \mu \mathrm{m}$-pore-size black Nucleopore filters and enumerated by epifluorescence microscopy (at $1.250 \times$ magnification). Samples for ciliate and metazoan communities were fixed with Lugol's solution $(1 \% \mathrm{v} /$ v) and settled for at least $24 \mathrm{~h}$ in plankton chambers. The ciliates and metazoans were counted and identified with an inverted microscope at 400-1000 $\times$ magnification. Ciliates are highly perishable, and their type of motility is a speciesspecific feature; for this reason, species determination and measurements were carried out on live material immediately after return to the laboratory and after silver impregnation (Augustin et al., 1984). Taxonomic identification was based primarily on Foissner and Berger (1996), Foissner et al. (1999). Chironomid larvae were collected from the periphyton using a Perspex cylindrical apparatus (length $32 \mathrm{~cm}$, diameter $13 \mathrm{~cm}$ ), with openings covered by $250 \mu \mathrm{m}$ mesh nets. The open apparatus was lowered into the macrophyte bed and a plant fragment was placed very gently inside the cylinder using a small floristic fork. The sampler was closed very slowly to minimize water movement and raised in a horizontal position to the surface. Shoots protruding beyond the top of the sampler were cut off. The water from the cylinder flowed out, the sampler was opened and the plant material was transferred to a plastic bag. Next, the sampler was placed in a vertical position and flushed with lake water to rinse animals remaining on the net to the bottom of the cylinder where they could be collected easily. In the laboratory, the larvae were removed from the macrophyte samples, preserved in $4 \%$ formaldehyde solution, counted and identified. Chironomidae larvae nomenclature followed Wiederholm (1983). Density was calculated per $100 \mathrm{~g}^{-1} \mathrm{DW}$ of plant. At each sampling site and on each sampling date (month), ten larvae of dominant taxa were selected for gut content analysis. The larvae were rinsed of any surface debris, decapitated, dissected along the length of their body, and placed in Eppendorf tubes filled with filtered water (GF/C filter). Each tube stored the contents of a single gut. The tubes were fixed on a shaker for $20 \mathrm{~min}$ to dislodge the gut contents from the digestive tube tissues. Next, the gut content solutions were placed separately in a $10 \mathrm{~mL}$ counting chamber and filled with filtered water $(\mathrm{GF} / \mathrm{C})$. After settling, algae, detritus and ciliates in the gut contents were identified and counted under an inverted microscope. The relative abundances of cyanobacteria, diatoms, chlorophytes and ciliates found in the gut were assessed as the percentage ratio of the total number of cells (filaments) of each group to the total number of particles counted on the slide. Each filament $100 \mu \mathrm{m}$ in length was calculated as one cell.

\subsection{Physical and chemical parameters}

Simultaneously to the biological examinations, a number of physical and chemical analyses were conducted. Visibility was estimated with a Secchi disc (SD). Temperature, conductivity, $\mathrm{pH}$ and dissolved oxygen (DO) were determined in situ with a multiparametric probe YSI-556MPS. Total suspended solids (TSS) and total organic carbon (TOC) were determined using a PASTEL UV spectrophotometer, and the remaining factors (Ptot - total phosphorus, $\mathrm{PO}_{4}-\mathrm{P}, \mathrm{NH}_{4}-\mathrm{N}$ and $\mathrm{NO}_{3}-\mathrm{N}$ ) were analysed in the laboratory (Golterman, 1969). Total phosphorus and ortophosphates were measured using a spectrophotometer UV-1610 Schimadzu (with molybdate method after mineralization with a mixture of $\mathrm{HNO}_{3}$ and $\mathrm{H}_{2} \mathrm{SO}_{4}$ ), nitrate (with sodium salicylate method) and $\mathrm{NH}_{4}-\mathrm{N}$ 
Table 1. Physical and chemical characteristic of studied lakes (mean values for spring-autumn $\pm \mathrm{SD}$ ).

\begin{tabular}{|c|c|c|c|c|c|}
\hline & Strat_lake & Cer_lake1 & Cer_lake2 & Pot_lake1 & Pot_lake2 \\
\hline Temperature ( $\left.{ }^{\circ} \mathrm{C}\right)$ & $21.2 \pm 1.1$ & $20.7 \pm 1.1$ & $19.7 \pm 0.9$ & $21.5 \pm 1.1$ & $20.8 \pm 1.0$ \\
\hline Secchi disc visibility (m) & $2.6 \pm 0.13$ & $0.4 \pm 0.02$ & $0.6 \pm 0.03$ & $0.8 \pm 0.04$ & $0.5 \pm 0.02$ \\
\hline $\mathrm{pH}$ & $8.4 \pm 0.42$ & $8.8 \pm 0.44$ & $8.8 \pm 0.44$ & $8.2 \pm 0.41$ & $8.2 \pm 0.38$ \\
\hline Conductivity $\left(\mu \mathrm{S} \cdot \mathrm{cm}^{-1}\right)$ & $244 \pm 12$ & $259 \pm 13$ & $283 \pm 11$ & $380 \pm 19$ & $343 \pm 17$ \\
\hline Total suspension $\left(\mathrm{mg} \cdot \mathrm{L}^{-1}\right)$ & $2.9 \pm 0.15$ & $11.2 \pm 0.56$ & $18.4 \pm 0.92$ & $27.5 \pm 1.37$ & $37.8 \pm 1.89$ \\
\hline Dissolved oxygen $\left(\mathrm{mg} \cdot \mathrm{L}^{-1}\right)$ & $9.1 \pm 0.45$ & $12.3 \pm 0.62$ & $10.3 \pm 0.59$ & $11.5 \pm 0.57$ & $13.7 \pm 0.68$ \\
\hline $\mathrm{NH}_{4}-\mathrm{N}\left(\mathrm{mg} \cdot \mathrm{L}^{-1}\right)$ & $0.098 \pm 0.04$ & $0.164 \pm 0.008$ & $0.108 \pm 0.005$ & $0.148 \pm 0.007$ & $0.091 \pm 0.005$ \\
\hline $\mathrm{NO}_{3}-\mathrm{N}\left(\mathrm{mg} \cdot \mathrm{L}^{-1}\right)$ & $0.080 \pm 0.004$ & $0.156 \pm 0.007$ & $0.120 \pm 0.006$ & $0.047 \pm 0.002$ & $0.085 \pm 0.004$ \\
\hline $\mathrm{PO}_{4}-\mathrm{P}\left(\mathrm{mg} \cdot \mathrm{L}^{-1}\right)$ & $0.053 \pm 0.002$ & $0.042 \pm 0.002$ & $0.054 \pm 0.003$ & $0.060 \pm 0.003$ & $0.026 \pm 0.001$ \\
\hline Ptot $\left(\mathrm{mg} \cdot \mathrm{L}^{-1}\right)$ & $0.066 \pm 0.003$ & $0.209 \pm 0.011$ & $0.231 \pm 0.012$ & $0.126 \pm 0.006$ & $0.080 \pm 0.004$ \\
\hline Chlorophyll- $a\left(\mu \mathrm{g} \cdot \mathrm{L}^{-1}\right)$ & $10.92 \pm 0.54$ & $46.21 \pm 2.3$ & $76.9 \pm 3.8$ & $60.43 \pm 3.1$ & $51.18 \pm 2.6$ \\
\hline TOC $\left(\mathrm{mg} \cdot \mathrm{L}^{-1}\right)$ & $4.5 \pm 0.5$ & $5.7 \pm 1.1$ & $6.5 \pm 0.7$ & $4.3 \pm 0.3$ & $5.3 \pm 1.4$ \\
\hline
\end{tabular}

by the Kjeldahl's method. Planktonic chlorophyll $a$ concentration was determined by spectrophotometric analysis of acetone extracts of algae retained on Whatman GF/F filters $(0.7 \mu \mathrm{m}$, $2.5 \mathrm{~cm}$ diameter) according to Golterman (1969).

\subsection{Statistical analyses}

Differences in the physical and chemical parameters and in abundance of periphyton communities among the studied sites were tested using factorial ANOVA (lake type, season). When significant differences were observed, the post-hoc sequential Bonferroni test was performed (Quinn and Keough, 2002). The initial critical probability value was set at $p<0.05 / n$, where $n=$ number of samples collected in lake $(n=18)$. Ordination techniques were used to describe the relationships between groups of the periphytic food web and environmental variables. The data were $\log$ transformed $\ln (x+1)$ prior to the analysis (Ter Braak, 1988-1992). The length of the gradient indicated by detrended correspondence analysis of the communities was $<2 \mathrm{SD}$, which suggests that principal component analysis (PCA) and redundancy analysis (RDA) were the appropriate methods (Ter Braak, 1988-1992). PCA was performed in order to confirm the separation of periphyton communities between macrophyte types of lakes. RDA analysis was performed in order to specify the effect of environmental variables on periphyton communities. The Monte Carlo permutation test (499 permutations) was applied to determine the significance $(p<0.05)$ of variables. All analyses were performed using CANOCO 4.5 for Windows. Pearson's correlation coefficients were calculated to determine the relationships between components of the periphytic food web with regard to lake types, using Statistica 10.0 Software.

\section{Results}

\subsection{Abiotic variables}

Environmental conditions (values of physical and chemical water parameters) showed high variability among the lake types and seasons (Tab. 1). Significant differences (results of factorial ANOVA) were noted for SD visibility $(F=11.87$;
$P<0.001)$, total suspension $(F=5.62 ; P<0.001), \mathrm{NH}_{4}-\mathrm{N}$ $(F=10.13 ; P<0.001), \mathrm{NO}_{3}-\mathrm{N}(F=4.28 ; P<0.015)$, Ptot $(F=28.94 ; P<0.011), \mathrm{PO}_{4}-\mathrm{P} \quad(F=53.26 ; P<0.001)$ and chlorophyll- $a(F=7.25 ; P<0.001)$.

\subsection{Microbial communities and Metazoa}

Biomass of periphytic algae varied significantly between lake types (ANOVA; $F=28.13 ; P<0.001$ ) and seasons (ANOVA; $F=16.27 ; P<0.001$ ) (Fig. 2a). In the Stratiotesdominated lake the highest biomass of periphytic algae $\left(22.7 \mu \mathrm{g} 100 \mathrm{~g}^{-1} \mathrm{DW}\right)$ was observed in spring and the lowest in autumn $\left(4.9 \mu \mathrm{g} 100 \mathrm{~g}^{-1} \mathrm{DW}\right)$. In the Ceratophyllumdominated lakes, biomass of periphytic algae varied from 11.5 and $13.3 \mu \mathrm{g} 100 \mathrm{~g}^{-1} \mathrm{DW}$ (summer) to 39.3 and $43.6 \mu \mathrm{g}$ $100 \mathrm{~g}^{-1} \mathrm{DW}$ (autumn); in the Potamogeton-dominated lakes we noted an increase in algal biomass from spring (36.4 and $\left.46.1 \mu \mathrm{g} 100 \mathrm{~g}^{-1} \mathrm{DW}\right)$ to autumn $\left(76.8\right.$ and $92.4 \mu \mathrm{g} 100 \mathrm{~g}^{-1}$ DW). We observed three main taxonomic groups of algae (chlorophytes, diatoms and cyanobacteria) on the macrophytes and in the lake types (Tab. 2, Fig. 2a). The abundance of bacteria ranged from $2 \times 10^{6}$ cells $100 \mathrm{~g}^{-1} \mathrm{DM}$ in the Stratiotes-dominated lake to $3.2 \times 10^{6}$ cells $100 \mathrm{~g}^{-1} \mathrm{DM}$ in the Ceratophyllum and Potamogeton-dominated lakes, and differed between the lakes $(F=16.29 ; P<0.001)$. In all lake types the highest abundances of bacteria were noted in spring and the lowest in autumn (Fig. 2b). The Ceratophyllumdominated lakes showed the lowest abundance of flagellates $\left(2 \times 10^{3}\right.$ cells $\left.100 \mathrm{~g}^{-1} \mathrm{DM}\right)$, while the highest abundance was found in the Potamogeton-dominated lakes $\left(3.3-4.2 \times 10^{3}\right.$ cells $\left.100 \mathrm{~g}^{-1} \mathrm{DM}\right)$. Flagellates reached their highest abundance in summer, while the levels observed in spring and autumn were similar $(F=17.27 ; P<0.001)$ (Fig. $2 \mathrm{c})$. Ciliata displayed differences in abundances: 23 cells $100 \mathrm{~g}^{-1} \mathrm{DM}$ in the Stratiotes-dominated lake, 35 cells $100 \mathrm{~g}^{-1} \mathrm{DM}$ in the Ceratophyllum-dominated lakes and 43 cells $100 \mathrm{~g}^{-1} \mathrm{DM}$ in the Potamogeton-dominated lakes. In most of the lakes studied peak abundances of ciliates were noted in spring and summer; only in the Ceratophyllum-dominated lake was ciliate abundance lowest in spring $(F=134.21 ; P<0.001)$. The dominance structure of the ciliate communities showed significant differences between lakes. The highest abundances 
A)
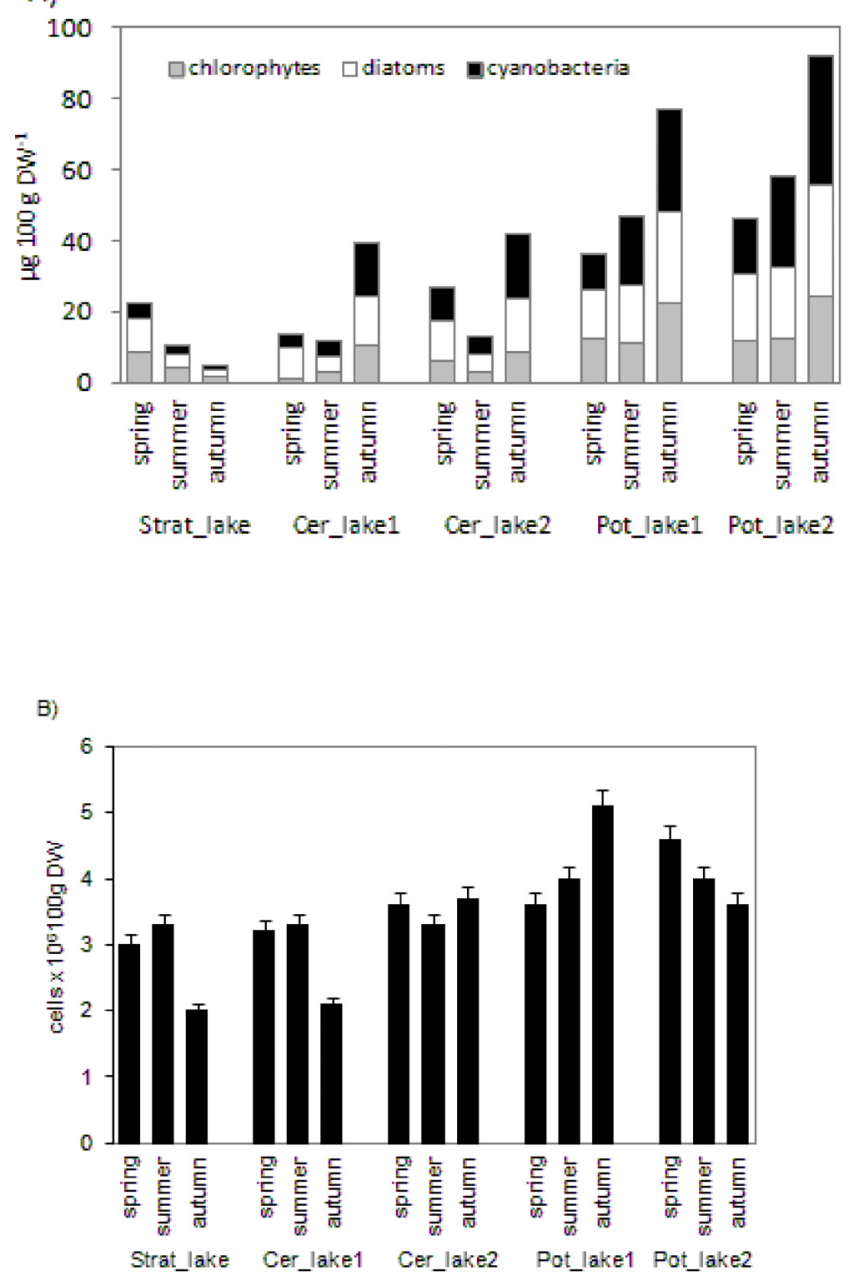

C)

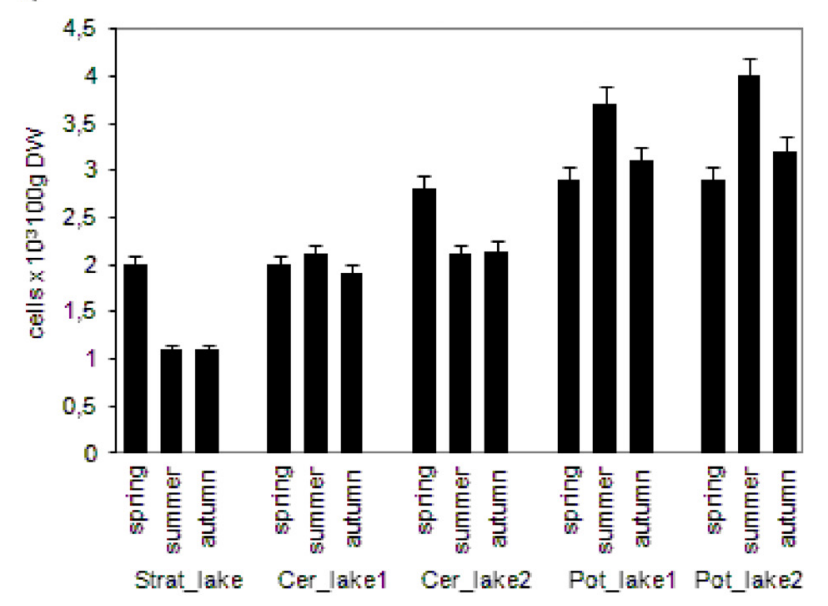

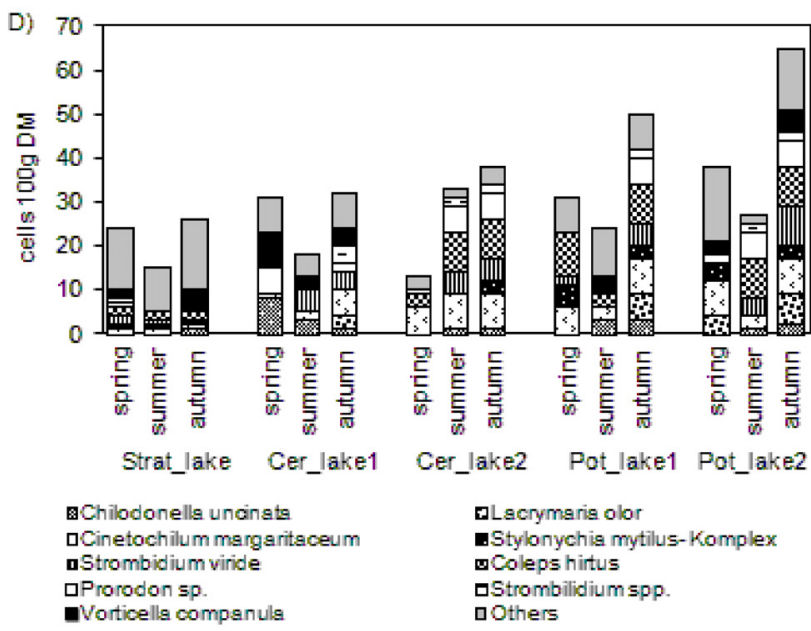

E)

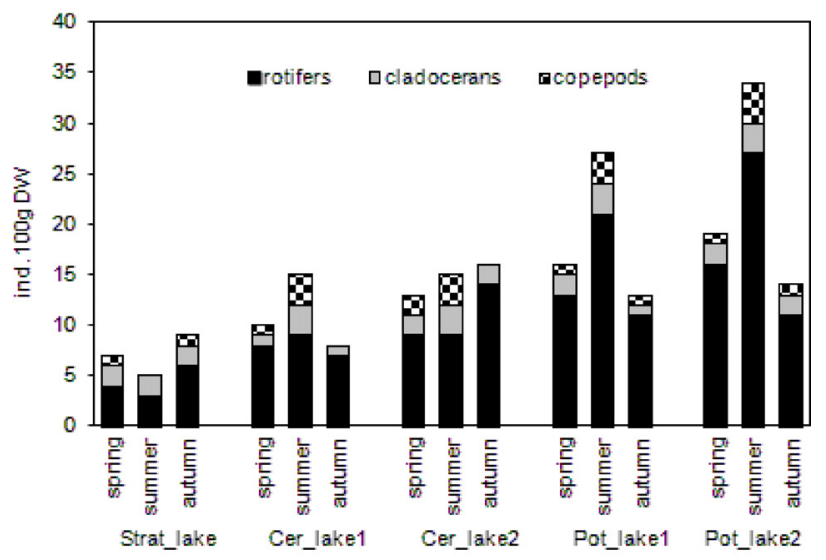

F)

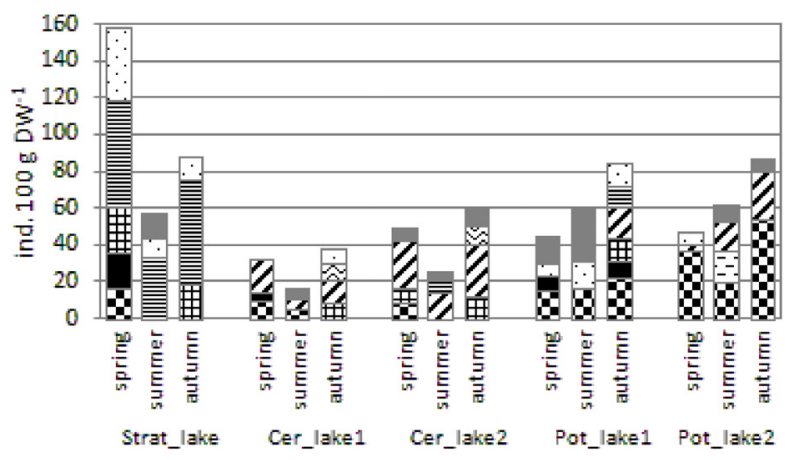

Fig. 2. Structure of periphytic food web components in lakes of different macrophyte community types: (A) algae, (B) bacteria, (C) flagellates, (D) ciliates, (E) metazoan, (F) chironomids. 
T. Mieczan et al.: Knowl. Manag. Aquat. Ecosyst. 2018, 419, 13

Table 2. Species composition of dominant groups of organisms found in periphyton in investigated lakes.

\begin{tabular}{llllll}
\hline Taxa/lake & Strat_lake & Cer_lake1 & Cer_lake2 & Pot_lake1 & Pot_lake2
\end{tabular}

\section{Algae \\ Chlorophyta}

Aphanochaete sp.

Bulbochaete sp.

Closterium sp.

Cosmarium sp.

Oedogonium sp.

Mougeotia sp.

Pediastrum sp.

Scenedesmus sp.

Ulothrix sp.

Zygnema sp.

Bacillariophyceae

Achnanthes sp.

Cocconeis sp.

Cymbella sp.

Diatoma sp.

Epithemia sp.

Fragillaria sp.

Gomphonema sp.

Navicula sp.

Pinnularia $\mathrm{sp.}$

Synedra sp.

Tabellaria sp.

Cyanoprokaryota

Anabaena sp.

Aphanizomenon sp.

Aphanothece sp.

Calothrix sp.

Geitlerinema sp.

Gleothrichia sp.

Limnothrix sp.

Lyngbya sp.

Microcistis sp.

Oscillatoria sp.

Planktothrix sp.

Pseudanabaena sp.

Rivularia sp.

Spirulina sp.

No. of taxa

Chilodonella uncinata

Cinetochilum margaritaceum

Coleps hirtus

Lacrymaria olor

Prorodon sp.

Stylonychia mytilus - Komplex

Strombidium viride

Strombilidium spp.

Vorticella companula

No. of taxa 
Table2. (continued).

\begin{tabular}{|c|c|c|c|c|c|}
\hline Taxa/lake & Strat_lake & Cer_lake1 & Cer_lake2 & Pot_lake1 & Pot_lake2 \\
\hline Keratella cochlearis tecta & $*$ & $*$ & $*$ & $*$ & $*$ \\
\hline Polyarthra sp. & & & & $*$ & $*$ \\
\hline Bdelloidea & $*$ & $*$ & $*$ & $*$ & $*$ \\
\hline No. of taxa & 5 & 4 & 4 & 6 & 6 \\
\hline \multicolumn{6}{|l|}{ Crustaceans } \\
\hline Bosmina longirostris & $*$ & $*$ & $*$ & $*$ & $*$ \\
\hline Ceriodaphnia quadrangula & $*$ & $*$ & $*$ & $*$ & $*$ \\
\hline Chydorus sphaericus & $*$ & & & $*$ & $*$ \\
\hline Diaphanosoma brachyurum & $*$ & $*$ & $*$ & $*$ & * \\
\hline No. of taxa & 4 & 3 & 3 & 4 & 4 \\
\hline \multicolumn{6}{|l|}{ Chironomid larvae } \\
\hline Ablabesmyia phatta & $*$ & & $*$ & & \\
\hline Cricotopus sp. (gr. sylvestris) & $*$ & $*$ & $*$ & $*$ & $*$ \\
\hline Psectrocladius sp. (gr. sordidellus) & $*$ & $*$ & & $*$ & \\
\hline Parachironomus sp. (gr. varus) & & & & & $*$ \\
\hline Dicrotendipes sp. & $*$ & $*$ & $*$ & $*$ & \\
\hline Endochironomus albipennis & $*$ & $*$ & $*$ & $*$ & $*$ \\
\hline Endochironomus impar & & $*$ & $*$ & $*$ & $*$ \\
\hline Glyptotendipes sp. & $*$ & & $*$ & $*$ & \\
\hline Phaenopsectra flavipes & $*$ & & & & \\
\hline Polypedilum sordens & & $*$ & $*$ & & \\
\hline Paratanytarsus austriacus & $*$ & $*$ & & $*$ & $*$ \\
\hline No. of taxa & 8 & 7 & 7 & 7 & 5 \\
\hline
\end{tabular}

were attained by Vorticella companula (Stratiotes-dominated lake), Chilodonella uncinata (Ceratophyllum-dominated lakes) and Cinetochilum margaritaceum (Potamogeton-dominated lakes) (Tab. 2, Fig. 2d). The abundances of rotifers, Cladocera and copepods ranged from 5 to 10 ind. $100 \mathrm{~g}^{-1} \mathrm{DM}$ in the Stratiotes-dominated lake to $15-25$ ind. $100 \mathrm{~g}^{-1} \mathrm{DM}$ in the Ceratophyllum and Potamogeton-dominated lakes, and differed between lakes and seasons $(F=124.28-134.11$; $P<0.001)$. Abundances of Metazoa generally increased in the summer, except in the Stratiotes-dominated lake, where they were lowest in the summer and increased in spring and autumn (Fig. 2e). Bdelloids, Chydorus sphaericus and Bosmina longirostris were more abundant in the spring and autumn samples, whereas in the summer samples the species Diaphanosoma brachyurum, and Ceriodaphnia quadrangula prevailed. The results of factorial ANOVA showed that the abundance of epiphytic chironomids was affected by lake type $(F=152.84, P<0.001)$ and season $(F=164.28 ; P<0.001)$ (Fig. 2f). The mean density of chironomid larvae ranged from 15 ind. $100 \mathrm{~g}^{-1}$ DW to 157 ind. $100 \mathrm{~g}^{-1} \mathrm{DW}$, and in all seasons the highest values were noted in the Stratiotes-dominated lake. In the Stratiotes-dominated lake, larvae of Glyptotendipes sp. showed the highest relative abundance. Larvae of Endochironomus albipennis dominated the epiphytic fauna in the Ceratophyllum-dominated lakes and larvae of Cricotopus sp. (gr. sylvestris) prevailed in the Potamogeton-dominated lakes (Tab. 2).

\subsection{Ordination analyses}

The results of PCA showed that $75.8 \%$ of the total variance of periphyton data is explained by Axis 1 (62.7\%) and Axis 2 $(13.1 \%)$. On the ordination plot, samples collected in the Stratiotes-, Potamogeton- and Ceratophyllum-dominated lakes are visibly separated (Fig. 3). RDA performed in order to specify the limiting factors for abundances of periphytic food web components showed important differences between lake types. In the Stratiotes-dominated lake, all variables together explained $55.4 \%$ of the total variance. Axis 1 and Axis 2 explained $45.1 \%$ and $10.3 \%$ of the variance of periphyton data. The variables that significantly $(P<0.05$, Monte Carlo permutation test) explained the variance in the abundance of periphyton communities were $\mathrm{PO}_{4}-\mathrm{P} \quad(\lambda=0.12, F=3.98$, $P=0.014), \mathrm{NO}_{3}-\mathrm{N}(\lambda=0.14, F=3.51, P=0.016)$ and TOC $(\lambda=0.49, F=9.49, P=0.012)$ (Fig. 4$)$. In the Ceratophyllumdominated lakes environmental variables explained $62.2 \%$ of the total variance of periphyton data. Axis 1 and Axis 2 explained $51.8 \%$ and $24.0 \%$ of the variance. The results of the Monte Carlo permutation test indicated that $\mathrm{NH}_{4}-\mathrm{N}(\lambda=0.33$, $F=4.86, P=0.018)$ and $\mathrm{PO}_{4}-\mathrm{P}(\lambda=0.18, F=3.39, P=0.026)$ were significant variables affecting the abundance of periphyton communities (Fig. 4). In the Potamogetondominated lakes the percentage of variance explained by environmental data was the highest, at $88.1 \%$. Axis 1 and Axis 2 explained $71.3 \%$ and $16.8 \%$ of the variance of periphyton 


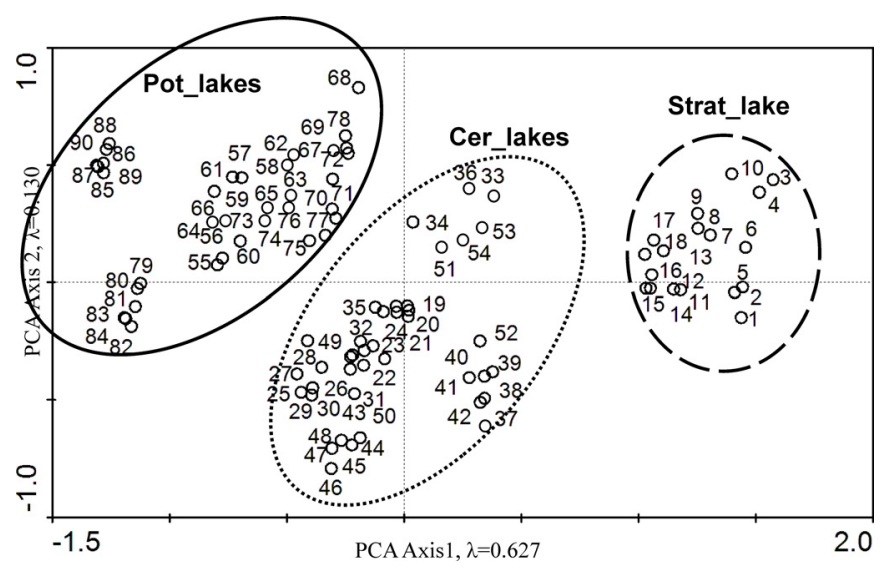

Fig. 3. Principal Component Analysis (PCA) scatter plot for axes 1 and 2 showing periphytic samples collecting in studied lake types. Axes are derived from the variation in the taxonomic data - matrix. Samples collected in studied lakes are marked with an Arabic numeral: 1-18 Stratiotes-dominated Lake Skomielno (Strat_lake); 19-36 Ceratophyllum-dominated Lake Białe Sosnowiskie (Cer_lake1); 37-54 Ceratophyllum dominated lake Dratów (Cer_lake2); 55-72 Potamogeton-dominated Lake Domaszne (Pot_lake1); 73-90 Potamogeton-dominated Lake Krzczeń (Pot_lake2).

data. Periphytic communities were significantly influenced by four environmental variables: temperature $(\lambda=0.13, F=3.54$, $P=0.036), \mathrm{SD}$ visibility $(\lambda=0.56, F=12.97, P=0.002)$, planktonic chlorophyll- $a(\lambda=0.65, F=13.12, P=0.018)$ and TOC $(\lambda=0.13, F=3.54, P=0.036)$ (Fig. 4$)$.

\subsection{Diet composition - gut content analysis}

Six food categories were observed in the diet of chironomid grazers in the lake types: detritus, ciliates, rotifers (bdelloids), cyanobacteria, diatoms and chlorophytes (Fig. 5). The relative abundances of ciliates (Cinetochilum sp., Colpidium colpoda, Paramecium sp., and Vorticella sp.) in the guts varied between $6 \%$ and $31 \%$. Rotifera (Bdelloids) constituted from $2 \%$ to $9 \%$ of total larval food. Moreover, algae, mostly small diatoms and cyanobacteria, were an important diet component; their relative abundances in the gut were high, oscillating between $8 \%$ and $56 \%$ for diatoms and from $3 \%$ to $47 \%$ or cyanobacteria. The dominant type of prey varied with time and lake type. In the Stratiotes-dominated lake, prey was dominated by chlorophytes and diatoms, while in the Ceratophyllum-dominated lakes cyanobacteria and diatoms were the main food for chironomid grazers and in the Potamogeton-dominated lakes detritus and ciliates dominated the dietary composition of grazers.

\subsection{Relationships between periphytic food web components}

The number of significant correlations between the main groups of the periphytic food web generally differed between the lake types (Tab. 3). Data analysis revealed a strong negative relationship in the Stratiotes-dominated lake between the abundance of bacteria and Metazoa (rotifers and cladocerans)
A)

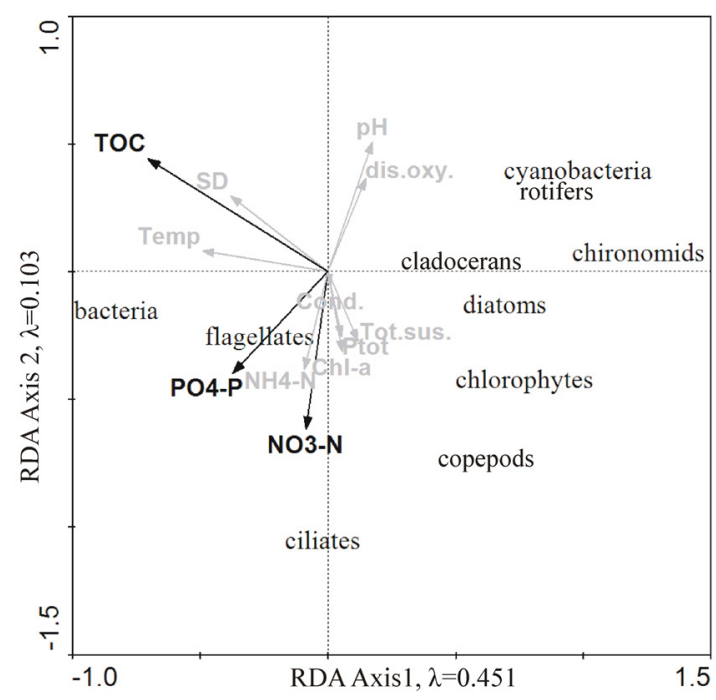

B)

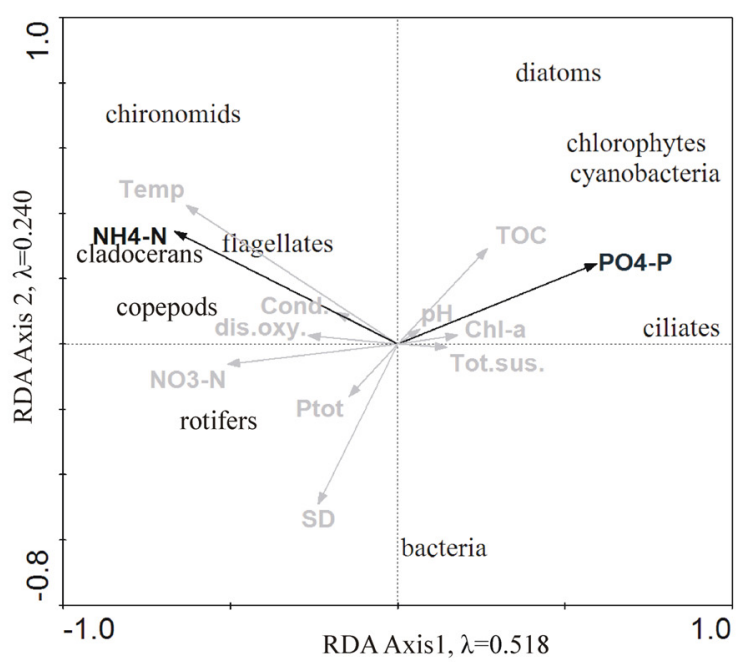

C)

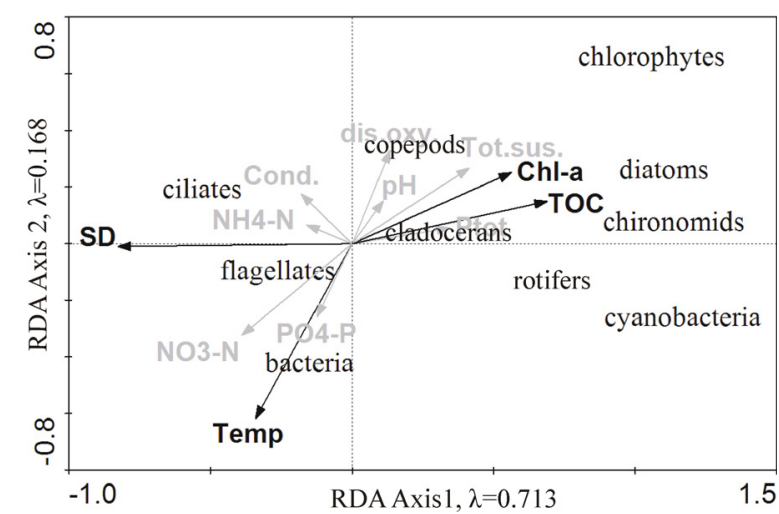

Fig. 4. Redundancy Analysis (RDA) biplots showing periphytic communities and environmental variables in: (A) Stratiotesdominated lake, (B) Ceratophyllum-dominated lakes and (C) Potamogeton-dominated lakes. Solid black arrows indicate significant variables based on Monte Carlo permutation test $(p<0.05)$. 


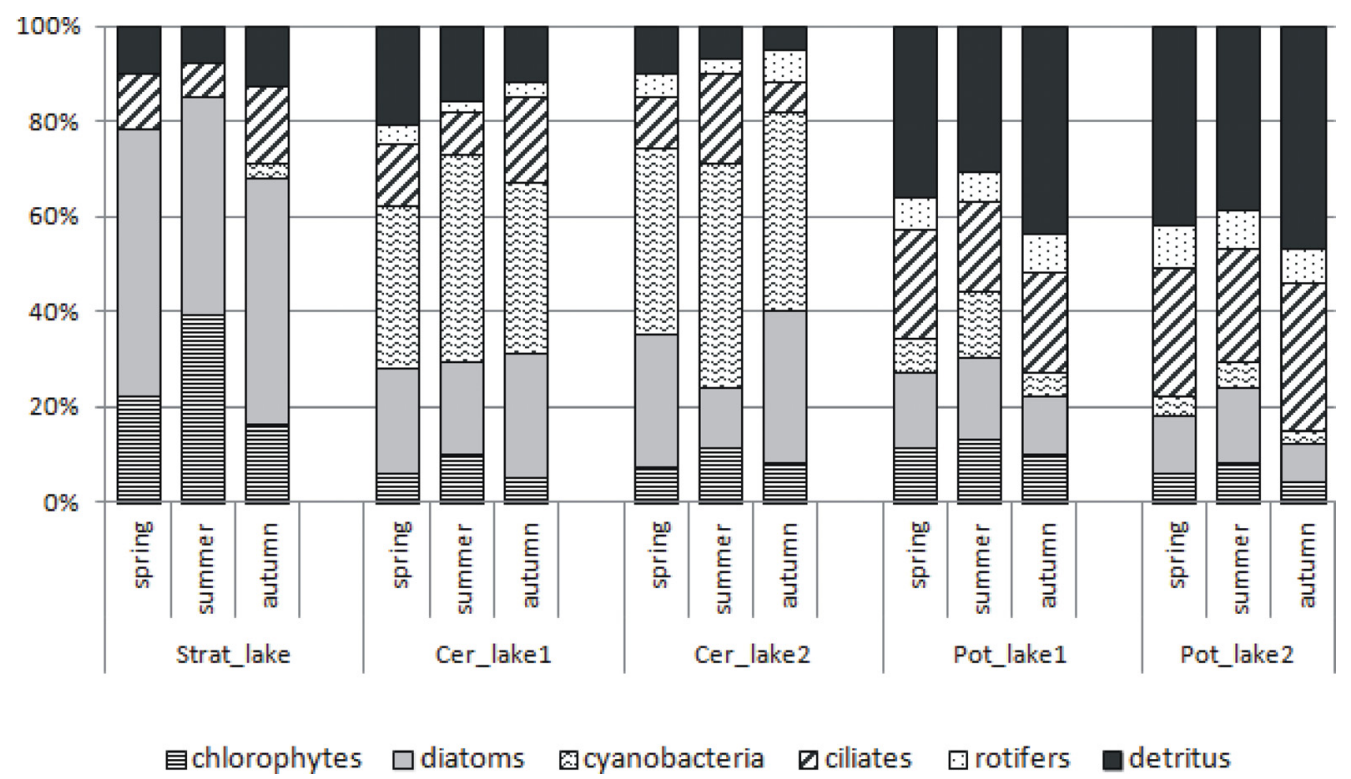

Fig. 5. Relative abundances of food items in the diet of chironomids in lakes of different macrophyte community types.

$(r=-0.92, P=0.001$ and $r=-0.54, P=0.02$ ), while the abundance of chironomids showed a strong negative correlation with the abundance of algae (chlorophytes and diatoms) $(r=-0.59, P<0.001$ and $r=-0.83, P<0.001)$, rotifers and cladocerans ( $r=0.90$, and $r=0.66, P<0.001$, respectively). In the Ceratophyllum-dominated lakes, flagellates showed a significant positive correlation with the density of rotifers, cladocerans and copepods $(r=0.66, r=0.47, r=0.50, P$ $<0.001)$. Chironomid density correlated positively with abundance of cladocerans $(r=0.60, P=0.001)$ and copepods $(r=0.65, p=0.048)$ and negatively with abundance of cyanobacteria $(r=-0.54, P=0.003)$. In the Potamogetondominated lakes, chironomid density showed a negative correlation with ciliates $(r=-0.63, P=0.001)$ and a positive relationship with density of chlorophytes and diatoms $(r=0.54$ and $\mathrm{r}=0.56, P=0.001)$. Bacterial density correlated positively with the density of flagellates $(r=0.60, P=0.0001)$, while flagellates and bacteria showed a negative correlation with density of ciliates $(r=-0.35, r=-0.44, P=0.036, P=0.007)$.

\section{Discussion}

\subsection{Food web vs. environmental parameters}

The results confirmed that under eutrophic conditions, submerged macrophytes markedly increased the colonization area for microbial communities (algae, bacteria and protists) and Metazoa. Variation partitioning based on RDA revealed that local factors played the most important roles in structuring the aquatic communities by explaining $55.4 \%-88.1 \%$ of their variation. The Monte Carlo permutation test showed that the food web components in the Potamogeton - and Ceratophyllum-dominated lakes were more strongly affected by water chemistry than in the Stratiotes-dominated lakes, where environmental variables were less important for abundances of food web components. Interestingly, different trophic relations were observed between lake types. In the Ceratophyllum-dominated lakes, which were more strongly affected by environmental variables, the relationships between food web components were weaker. Both species richness and abundance of algae and epiphytic fauna reached their highest values in the Stratiotes-dominated lake, while the species richness and abundance of microbial communities and Metazoa increased in the Ceratophyllum-dominated lakes and reached their highest values in the Potamogetondominated lakes. Similar patterns have been observed in planktonic microbial communities inhabiting these water bodies (Adamczuk et al., 2015). The structure of periphyton communities on the substrates studied was correlated with the productivity of the lakes. In the Stratiotes-dominated lakes algae were dominated by diatoms, while in the Potamogetonand Ceratophyllum-dominated lakes the contribution of filamentous cyanophytes increased. This group of algae occurs relatively frequently when mineral forms of nitrogen and phosphorus increase in the water (Gaiser et al., 2005). This was particularly evident in the Potamogeton-dominated lakes, where algae biomass reached values typical of hypertrophic lakes (Hitzfeld et al., 2000). The interaction between plants and periphyton may depend on the active release of allelochemical or growth stimulations, or can be passive through competition of light, nutrients and time of colonization (Grutters et al., 2017). It is difficult to disentangle these factors because plants and periphyton are intimately tied together. As indicated by the study performed by Mulderij et al. (2007) $S$. aloides has stronger allelopathic activity than other macrophyte species, which may result in the reduction of phytoplankton biomass even by $80 \%$. Moreover, during the summer, $S$. aloides often floats on the water and has a potential shading effect on algae. In addition, previous studies have indicated that phytoplankton species are more sensitive than periphyton to allelochemicals (Gross, 2003), and that cyanobacteria are more sensitive than green algae and diatoms to allelopathic substrates (Hao et al., 2017). However, in our study, the cyanobacteria biomass and the composition of periphyton did not show clear differences between Potamogeton- and Ceratophyllum-dominated lakes. Lower concen- 
Table 3. Relationships (values of Pearson correlation coefficient, $r$ ) between components of periphytic food web in lakes of different macrophyte community types.

\begin{tabular}{|c|c|c|c|c|c|c|c|c|c|c|}
\hline & Chlo & Dia & Суa & $\mathrm{Bac}$ & Fla & Cil & Rot & Cla & Cop & Chir \\
\hline \multicolumn{11}{|c|}{ Strat_lake } \\
\hline Chlo & $\mathrm{ns}$ & $\mathrm{ns}$ & ns & ns & $\mathrm{ns}$ & $0.54^{*}$ & ns & $\mathrm{ns}$ & ns & $-0.59^{* *}$ \\
\hline Dia & $\mathrm{ns}$ & $\mathrm{ns}$ & ns & $\mathrm{ns}$ & $\mathrm{ns}$ & $0.38^{*}$ & $-0.34^{*}$ & $\mathrm{~ns}$ & $\mathrm{~ns}$ & $-0.83^{* *}$ \\
\hline Суа & $\mathrm{ns}$ & $\mathrm{ns}$ & $\mathrm{ns}$ & $\mathrm{ns}$ & $\mathrm{ns}$ & $0.57^{* *}$ & ns & ns & $\mathrm{ns}$ & ns \\
\hline $\mathrm{Bac}$ & $\mathrm{ns}$ & ns & $\mathrm{ns}$ & $\mathrm{ns}$ & $\mathrm{ns}$ & $\mathrm{ns}$ & $-0.92^{* *}$ & $-0.54^{*}$ & $\mathrm{~ns}$ & $\mathrm{~ns}$ \\
\hline Fla & ns & ns & ns & $\mathrm{ns}$ & $\mathrm{ns}$ & $\mathrm{ns}$ & $0.67^{* *}$ & ns & $\mathrm{ns}$ & $\mathrm{ns}$ \\
\hline Cil & $0.54^{*}$ & $0.38^{*}$ & $0.57^{* *}$ & ns & ns & $\mathrm{ns}$ & ns & ns & $\mathrm{ns}$ & ns \\
\hline Rot & $\mathrm{ns}$ & $-0.34^{*}$ & ns & $-0.92^{* *}$ & $0.67^{* *}$ & ns & ns & ns & ns & $0.90^{* *}$ \\
\hline $\mathrm{Cla}$ & $\mathrm{ns}$ & $\mathrm{ns}$ & ns & $-0.54^{*}$ & ns & $\mathrm{ns}$ & $\mathrm{ns}$ & $\mathrm{ns}$ & ns & $0.66^{* *}$ \\
\hline Cop & ns & ns & ns & ns & $\mathrm{ns}$ & ns & ns & $\mathrm{ns}$ & ns & ns \\
\hline Chir & $-0.59^{* *}$ & $-0.83^{* *}$ & ns & $\mathrm{ns}$ & ns & ns & $0.90^{* *}$ & $0.66^{* *}$ & $\mathrm{~ns}$ & $\mathrm{~ns}$ \\
\hline \multicolumn{11}{|c|}{ Cer_lakes } \\
\hline Chlo & ns & ns & ns & $\mathrm{ns}$ & ns & $0.54^{*}$ & ns & ns & ns & ns \\
\hline Dia & $\mathrm{ns}$ & ns & $\mathrm{ns}$ & $\mathrm{ns}$ & $\mathrm{ns}$ & ns & $\mathrm{ns}$ & ns & ns & ns \\
\hline Суа & $\mathrm{ns}$ & $\mathrm{ns}$ & $\mathrm{ns}$ & $\mathrm{ns}$ & $\mathrm{ns}$ & $0.58^{* *}$ & $\mathrm{~ns}$ & $\mathrm{~ns}$ & $\mathrm{~ns}$ & $-0.54^{* *}$ \\
\hline $\mathrm{Bac}$ & ns & ns & ns & ns & ns & ns & ns & ns & ns & $\mathrm{ns}$ \\
\hline Fla & ns & ns & ns & $\mathrm{ns}$ & ns & ns & $0.66^{* *}$ & $0.47^{* *}$ & $0.50^{* *}$ & ns \\
\hline Cil & $0.54^{*}$ & ns & $0.58^{* *}$ & $\mathrm{~ns}$ & ns & ns & $-0.65^{* *}$ & $-0.62^{* *}$ & $-0.60^{* *}$ & ns \\
\hline Rot & ns & ns & $\mathrm{ns}$ & $\mathrm{ns}$ & $0.66^{* *}$ & ns & ns & ns & ns & $\mathrm{ns}$ \\
\hline $\mathrm{Cla}$ & $\mathrm{ns}$ & $\mathrm{ns}$ & $\mathrm{ns}$ & $\mathrm{ns}$ & $0.47^{* *}$ & $\mathrm{~ns}$ & $\mathrm{~ns}$ & $\mathrm{~ns}$ & $\mathrm{~ns}$ & $0.60^{* *}$ \\
\hline Cop & $\mathrm{ns}$ & $\mathrm{ns}$ & ns & $\mathrm{ns}$ & $0.50^{* *}$ & $\mathrm{~ns}$ & $\mathrm{~ns}$ & ns & ns & $0.65^{*}$ \\
\hline Chir & ns & ns & $-0.54^{* *}$ & ns & ns & ns & $\mathrm{ns}$ & $0.60^{* *}$ & $0.65^{*}$ & ns \\
\hline \multicolumn{11}{|c|}{ Pot lakes } \\
\hline Chlo & ns & ns & ns & ns & $\mathrm{ns}$ & ns & $0.51^{*}$ & ns & ns & $0.54^{* *}$ \\
\hline Dia & $\mathrm{ns}$ & ns & ns & $\mathrm{ns}$ & ns & ns & $0.55^{*}$ & ns & ns & $0.56^{* *}$ \\
\hline Cya & ns & ns & ns & $\mathrm{ns}$ & ns & ns & $0.53^{*}$ & ns & ns & $-0.62^{* *}$ \\
\hline $\mathrm{Bac}$ & ns & ns & ns & ns & $0.60^{* *}$ & $-0.44^{*}$ & ns & ns & $\mathrm{ns}$ & $\mathrm{ns}$ \\
\hline Fla & ns & $\mathrm{ns}$ & $\mathrm{ns}$ & $0.60^{* *}$ & $\mathrm{~ns}$ & $-0.35^{*}$ & ns & $\mathrm{ns}$ & ns & $\mathrm{ns}$ \\
\hline Cil & ns & ns & ns & $-0.44^{*}$ & $-0.35^{*}$ & $\mathrm{~ns}$ & $\mathrm{~ns}$ & ns & $\mathrm{ns}$ & $-0.63^{* *}$ \\
\hline Rot & $0.51^{*}$ & $0.55^{*}$ & $0.53^{*}$ & ns & $\mathrm{ns}$ & ns & ns & $\mathrm{ns}$ & $\mathrm{ns}$ & $\mathrm{ns}$ \\
\hline Cla & $\mathrm{ns}$ & ns & $\mathrm{ns}$ & $\mathrm{ns}$ & ns & $\mathrm{ns}$ & $\mathrm{ns}$ & $\mathrm{ns}$ & $\mathrm{ns}$ & ns \\
\hline Cop & ns & ns & ns & $\mathrm{ns}$ & ns & $\mathrm{ns}$ & $\mathrm{ns}$ & ns & $\mathrm{ns}$ & ns \\
\hline Chir & $0.54^{* *}$ & $0.56^{* *}$ & $-0.62^{* *}$ & $\mathrm{~ns}$ & ns & $-0.63^{* *}$ & ns & ns & ns & ns \\
\hline
\end{tabular}

$n=18$ per lake (total $n=90$ ); ns $p>0.05 ; * 0.05<p<0.01 ; * * 0.01<p<0.001$; Chlo-chlorophytes, Dia-diatyoms, Cya-cyanophytes, Bacbacteria, Fla-flagellates, Cil-ciliates, Rot-rotifers, Cla-cladocerans, Cop-copepods, chir-chironomids.

trations of chlorophyll- $a$ in Stratiotes-dominated lakes were probably a results of the allelopathic effect of Stratiotes species.

Our study results indicate that periphyton communities are regulated by similar factors as in other parts of the world (Vermaat, 2005). The strongest correlation was found between periphytic assemblages and both temperature and nutrients. In eutrophic shallow lakes, periphytic assemblages have been shown to be associated with $\mathrm{P}_{\text {tot }}$ and $\mathrm{N}_{\text {tot }}$ (Jones and Sayer, 2003), and with a combination of physical variables, e.g. water level, and chemical variables, such as $\mathrm{pH}, \mathrm{N}$, and DOC (Mieczan et al., 2016). The RDA showed that nutrients were the dominant factors controlling distribution patterns in ciliate assemblages. This is reflected in an increase in the contribution of species typical of relatively eutrophic environments. The dominant ciliates in our study were eurytopic, bacterivorous species which have rapid ecological adaptability and a wide range of tolerance for environmental changes. This suggests that ciliates in eutrophic ecosystems constitute a significant link in the flow of matter and energy between bacteria and higher invertebrates. The small proportion of algivorous and algae-diatom feeder ciliates in the habitats studied may have been caused by problems with food availability, as the periphyton was dominated by filamentous algae, which are not often consumed by protozoans. Filamentous algae, even cyanobacteria, can be selectively consumed by macroinvertebrate grazers, such as the chironomid Endochironomus albipennis. Selective foraging on filamentous algae may significantly reduce their biomass (Tarkowska-Kukuryk, 2013; Mieczan et al., 2016). Temperature is another factor likely to substantially influence periphyton succession. According to Mieczan and Tarkowska-Kukuryk (2013), the growth and reproduction of freshwater microbial communities in the periphyton were strongly correlated with temperature. The temperature in the lakes studied had a significant influence on the number of algae and microorganisms. Furthermore, the concentration of TOC was found to significantly influence the occurrence of individual components of the periphytic food 
web. According to studies by many authors (Haglund and Hillebrand, 2005; Mieczan and Tarkowska-Kukuryk, 2011), irrespective of trophic status organic carbon primarily affects the abundance of bacteria. This is also reflected in the present study, as the abundance of these microbes was several times higher in the Potamogeton-dominated-lakes, which had the highest concentrations of TOC.

\subsection{Interactions between food web components}

According to the literature (McQueen et al., 1986, 1989; Brett and Goldman, 1996) the influence of predator activity control on lower trophic levels generally decreases with increasing nutrient levels, but some studies suggest that topdown control is in fact most pronounced in nutrient-rich lakes (Leibold, 1996; Sarnelle, 1992; Jeppesen et al., 1997). Our study showed that in the Stratiotes- and Ceratophyllumdominated lakes a marked decrease was noted in the biomass of periphytic algae in the seasons in which the highest density of epiphytic fauna was observed. No similar relationship was observed in the Potamogeton-dominated lakes. In these lakes a high biomass of periphytic algae was noted in autumn. During this period the concentrations of mineral forms of nitrogen and phosphorus increased as well. This could be the effect of the substantial density of chironomid larvae, which may have caused an increase in habitat fertility through excretion. Literature data indicate that chironomid larvae can supply from 140 to $305 \mu \mathrm{g} \mathrm{N} \mathrm{mg} \mathrm{dry} \mathrm{w}{ }^{-1} \mathrm{~d}^{-1}$ to their environment (Fukuharada and Yasuda, 1989). Thus it seems that they can influence periphytic microbial communities through the mechanisms of both bottom-up regulation and top-down regulation, as top-predators. In addition, allelochemicals releasing from macrophytes decreasing survival or changed behaviors of some invertebrate taxa - dipteran larvae, but the concentration and effectiveness of such substrates varied with macrophyte species (Zeng et al., 2017). Gross (2003) reported that allelopathic substrates have been documented for Ceratophyllum and Myriophyllum but, are rare among Potamogeton species. Therefore, macrophyte-specific allelopathic influences on some aquatic organisms also seemed to be independent of macrophyte architecture.

Our study suggested that both nutrients and macroinvertebrates both determine the abundance of protozoa. Nutrients seem to indirectly determine the prevalence of ciliates and macroinvertebrates through the control of food abundance (mainly bacteria and algae).

Analysis of the guts of chironomid larvae indicates that they significantly influence not only algae biomass but also the abundance and biomass of protozoans - mainly ciliates. These microbes accounted for $19 \%$ to $31 \%$ of the food of chironomid larvae, depending on the type of lake, with their largest share in the diet of grazers noted in the Potamogeton-dominated lakes. Chironomid grazers were dominated by larvae of Cricotopus sp. (gr. sylvestris). These larvae are collector-gatherers that primarily ingest large amounts of detritus (TarkowskaKukuryk and Mieczan, 2008). Moreover, in the Potamogeton-dominated lakes a marked decrease was observed in the abundance of periphytic rotifers in the summer and autumn, which may have significantly affected the other elements of the microbial food web. Literature data indicate that rotifers can consume up to 5 ciliates per hour (Arndt, 1993). Brachionus,
Keratella and Filinia may play a key role in the consumption of small ciliate taxa, while Asplanchna and Polyarthra efficiently consume large protozoan taxa (Arndt, 1993). Mainly rotifers of the Bdelloidea class were dominant in the gut of chironomid larvae. A study by Tarkowska-Kukuryk and Mieczan (2008) showed that they feed primarily on bacteria, ciliates and detritus. Consumption of rotifers and protozoans by chironomid larvae also transformed the trophic structure of these microbes, decreasing the share of bacterivorous species and increasing that of omnivorous species. The larvae most often consumed smaller taxa and left larger taxa. In addition, a considerable decrease in the abundance of protozoans (mainly ciliates), but also of bacteria and flagellates, was observed in the summer in all lake types. At the same time no clear increase was noted in the abundance of predators. However, during this period an increase in water temperature was observed as compared to the other sampling times. According to the 'metabolic theory', predator activity increases as the temperature rises, and thus top-down control becomes stronger (Brown et al., 2004). Hence it is likely that an increase in the consumption efficiency of top predators contributed to the decrease in the abundance and biomass of most of the microorganisms. The marked increase in ciliate abundance in the spring and autumn in all lake types probably influenced the abundance of bacteria. This may have been linked to an increase in the proportion of small, bacterivorous species of ciliates, mainly Colpodea and Scuticociliatida.

Summing up, the relations demonstrated between bacteria, protozoa and macroinvertebrates may point to an important process of matter and energy flow from bacteria to higher trophic levels. In Stratiotes-dominated lake, relations between food web components were stronger. Knowledge of periphytic food webs in shallow lakes ecosystems is still scarce, although it is crucial for understanding their function. However, with the aim of clarifying the understanding of the role of factors conditioning the functioning of food webs, it is necessary in future research to explain experimentally interactions between micro-organisms and macro-invertebrates.

\section{References}

Adamczuk M, Mieczan T, Nawrot D, Rechulicz J. 2015. Indirect effect of environmental factors on interactions between microbial and classical food webs in freshwater ecosystems. Ann LimnolInternat J Limnol 51: 49-58.

Arndt H. 1993. Rotifers as predators on components of the microbial web (bacteria, heterotrophic flagellates, ciliates) - a review. Hydrobiologia 256: 231-246.

Augustin H, Foissner W, Adam H. 1984. An improved pyridinated silver carbonate method which need few specimens and yields permanent slides of impregnation ciliates (Protozoa, Ciliophora). Mikroskopie 41: 134-137.

Biyu S. 2000. Planktonic protozooplankton (ciliates, heliozoans and testaceans) in two shallow mesotrophic lakes in China - a comparative study between a macrophyte-dominated lake (Biandantang) and algal lake (Houhu). Hydrobiologia 434: 151-163.

Brett MT, Goldman CR. 1996. A meta-analysis of the freshwater trophic cascade. Proceed Nat Acad Sci 93: 7723-7726.

Caron DA. 1983. Technique for enumeration of heterotrophic and phototrophic nanoplankton, using epifluorescence microscopy and 
comparison with other procedures. Appl Environ Microbiol 46: 491-498.

Dawidek J, Sobolewski S, Turczyński M. 2004. Transformations of catchmet-areas of lakes converted into storage reservoirs in the Wieprz-Krzna Canal system. Limnol Rev 4: 67-74.

Enterkin SA, Wallace JB, Eggert SL. 2007. The response of Chironomidae (Dipetra) to a long term exclusion of terrestrial organic matter. Hydrobiologia 575: 401-413.

Fermani P, Diovisalvi N, Torremorell A, Lagomarsioni L, Zagarese HE, Unrein F. 2013. The microbial food web structure of a hypertrophic warm-temperate shallow lake, as affected by contrasting zooplankton assemblages. Hydrobiologia 714: 115-130.

Foissner W, Berger H. 1996. A user-friendly guide to the ciliates (Protozoa, Ciliophora) commonly used by hydrobiologists as bioindicators in rivers, lakes and waste waters, with notes on their ecology. Freshw Biol 35: 375-470.

Foissner W, Berger H, Schaumburg J. 1999. Identification and ecology of limnetic plankton ciliates. Informationsberichte des Bayer. München: Landesamtes für Wasserwirtschaft.

Fukuharada H, Yasuda K. 1989. Ammonium excretion by some freshwater zoobenthos from a eutrophic lake. Hydrobiologia 173: $1-8$.

Gaiser EE, Texler J.C, Richards JH, Childers DL, Lee D, Edwards AL, Scinto LJ, Jayachandaran K, Noe GB, Jones RD. 2005. Cascading ecological effects of low-level phosphorous enrichment in the Florida Everglades. J Environ Qual 34: 717-723.

Golterman HL. 1969. Methods for chemical analysis of freshwaters. Oxford, Edinburgh: Blackwell Scientific Publications.

Gross EM. 2003. Allelopathy in aquatic autotrophs. Crit Rev Plant Sci 22: $313-339$.

Grutters BMC, Gross EM, van Donk E, Bakker ES. 2017. Periphyton density is similar on native and non-native plant species. Freshwat Biol 62: 906-915.

Haglund AL, Hillebrand H. 2005. The effect of grazing and nutrient supply on periphyton associated bacteria. FEMS Microbiology Ecology 52: 31-41.

Hao B, Wu H, Cao Y, Xing W, Jeppesen E, Li W. 2017. Comparison of periphyton communities on natural and artificial macrophytes with contrasting morphological structures. Freshwat Biol 62: 17831793.

Hitzfeld BC, Hőger SJ, Dietrech DR. 2000. Cyanobacterial toxins: removal during drinking water treatment, and human risk assessment. Environ Health Perspect 108: 113-122.

Jeppesen E, Jensen JP, Søndergaard M, Lauridsen T, Pedersen LJ, Jensen L. 1997. Top-down control in freshwater lakes: the role of nutrient state, submerged macrophytes and water depth. Hydrobiologia 342/343: 151-164.

Jeppesen E, Lauridsen TL, Kairesalo T, Perrow MR. 1998. Impact of submerged macrophytes on fish-zooplankton interactions in Lakes. In: Jeppesen E, Søndergaard M, Søndergaard M, Christoffersen K. eds. The structuring role of submerged macrophytes in Lakes. New York: Springer Verlag, pp. 91-114.

Jeppesen E, Jensen PJ, Sondegaard M, Lauridsen T, Landkildehus F. 2000. Trophic structure, species richness and biodiversity in Danisch lakes: changes along a phosphorus gradient. Freshw Biol 45: 201-218.

Jeppesen E, Sondergaard M, Meerhoff M, Lauridsen TL, Jensen JP. 2007. Shallow lake restoration by nutrient loading reduction some recent findings and challenges ahead. Hydrobiologia 584: 239-252.

Jones JI, Moss B, Eaton JW, Young JO. 2000. Do submerged aquatic plants influence periphyton community composition for the benefit of invertebrate mutualists? Freshw Biol 43: 591-604.
Jones JI, Sayer CD. 2003. Does the fish-invertebrate-periphyton cascade precipitate plant loss in shallow lakes? Ecology 84: 21552167.

Kairesalo T, Kornijów R, Luokkanen E. 2000. Trophic cascade structuring a plankton community in a strongly vegetated lake littoral. Verh Int Verein Limnol 26: 1846-1851.

Lawrence JM, Gresens SE. 2004. Food web response to nutrient enrichment in rural and urban streams. J Freshw Ecol 3: 375385.

Leibold MA. 1996. A graphical model of keystone predators in food webs: trophic regulation of abundance, incidence, and diversity patterns in communities. Am Nat 147: 784-812.

McQueen DJ, Post JR, Mills EL. 1986. Trophic relationships in freshwater pelagic ecosystems. Can J Fish Aquat Sci 43: 15711581.

McQueen DJ, Johannes MR, Post JR, Stewart TJ, Lean DR. 1989. Bottom-up and top-down impacts on freshwater pelagic community structure. Ecol Monogr 59: 289-309.

Mieczan T, Tarkowska-Kukuryk M. 2013. Diurnal dynamics of the microbial loop in peatlands: structure, function and relationship to environmental parameters. Hydrobiologia 717: 189-201.

Mieczan T, Adamczuk M, Tarkowska-Kukuryk M, Nawrot D. 2016. Effect of water chemistry on zooplanktonic and microbial communities across freshwater ecotones in different macrophyte-dominated shallow lakes. J Limnol 2: 262-274.

Mulderij G, van Nes EH, van Donk E. 2007. Macrophytephytoplankton interactions: the relative importance of allelopathy versus other factors. Ecol Model 204: 85-92.

Obolewski K, Bąkowska M. 2017. Epiphytic invertebrate patterns in coastal lakes along a gradient of salinity and water exchange with the sea. Estuar, Coast Shelf Sci 197: 150-158.

Pierce RW, Turner JT. 1992. Ecology of planktonic ciliates in marine food webs. Rev Aquat Sci 6: 139-181.

Pomeroy LR. 1974. The ocean's food web, a changing paradigm. Bioscience 24: 499-504.

Porter KG, Fleig YS. 1980. The use of DAPI for identifying and counting aquatic microflora. Limnol Oceanogr 25: 943-948.

Quinn GP, Keough MJ. 2002. Experimental design and data analysis for biologists. Cambridge: Cambridge University Press.

Rott E. 1981. Some results from phytoplankton counting intercalibrations. Swiss J Hydrol 43: 34-62.

Sarnelle O. 1992. Nutrient enrichment and grazer effects on phytoplankton in lakes. Ecology 73: 551-560.

Segovia BT, Pereira DG, Bini LM, de Meira BR, Nishida S, LansacToha FA, Velho LFM. 2015. The role of microorganisms in a planktonic food web of a floodplain lake. Microb Ecol 69: 225233.

Schindler DE, Scheuerell MD. 2002. Habitat coupling in lake ecosystems. Oikos 57: 25-41.

Ter Braak CJF. 1988-1992. CANOCO-FORTRAN program for Canonical Community Ordination (version 2.1). Ithaca: Microcomputer Power.

Tarkowska-Kukuryk M, Mieczan T. 2008 Diet composition of epiphytic chironomids of the Cricotopus sylvestris group in a shallow hypertrophic lake. Aquat Insects 30: 285-294.

Tarkowska-Kukuryk M. 2013. Periphytic algae as food source for grazing chironomids in a shallow phytoplankton dominated lake. Limnologic 43: 254-264.

Tarkowska-Kukuryk M, Mieczan T. 2017. Submerged macrophytes as bioindicators of environmental conditions in shallow lakes in eastern Poland. Ann Limnol - Int J Lim 53: 27-34.

van den Hoek C, Mann DG, Jahns HM. 1995. Algae. An introduction to phycology. Cambridge: Cambridge University Press, 623 p. 
Vermaat JE. 2005. Periphyton dynamics and influencing factors. In: Azim ME, Verdegem MCJ, van Dam AA, Beveridge MCM eds. Periphyton. Ecology, exploitation and management. London, UK: CABI Publishing, pp. 35-49.

Wickham SA, Nagel S, Hillebrand H. 2004. Control of epibenthic ciliate communities by grazers and nutrients. Aquat Microb Ecol 35: $153-162$.

Wiederholm T. 1983. Chironomidae of the Holarctic region. Keys and diagnoses. Part 1. Larvae. Entomologica scandinavica. Supplement 19. Motala: Borgströms Tryckeri AB, 538 p.

Wetzel RG. 1990. Land-water interfaces: metabolic and limnological regulators. Int Ver Theor Angew Limnol 24: 6-24.
Xu J, Xie P, Zhang M, Yang H. 2005. Variation in stable isotope signatures of seston and a zooplanktivorous fish in a eutrophic Chinese lake. Hydrobiologia 541: 215-220.

Zeng L, Liu B, Dai Z, Zhou Q, Kong L, Zhang Y, He F, Wu Z. 2017. Analyzing the effect of four submerged macrophytes with two contrasting architectures on zooplankton: a mesocosm experiment. J Limnol 76: 581-590.

Zhang N, Li H, Jeppesen E, Li W. 2013. Influence of substrate type on periphyton biomass and nutrient state at contrasting high nutrient levels in a subtropical shallow lakes. Hydrobiologia 710: $129-141$.

Cite this article as: Mieczan T, Tarkowska-Kukuryk M, Ârva D, Berzni-Nagy L, Novak Z, Vajda C. 2018. The effect of epiphytic macroinvertebrates on microbial communities in different types of macrophyte-dominated shallow lakes. Knowl. Manag. Aquat. Ecosyst., 419,13 . 